\title{
Study of Microbiological Quality along the Water Chain in Belbedji in the Republic of Niger
}

\author{
Salifou Issa ${ }^{1,2 *}$, Daouda Mama1, Adamou Zanguina ${ }^{3}$, Ibrahim Natatou ${ }^{3}$, Mousa Boukari1, \\ Dominique Sohounhloué 4
}

\begin{abstract}
${ }^{1}$ Laboratoire d'Hydrologie Appliquée, Institut National de l'Eau (INE), Université d'Abomey-Calavi, Cotonou, Bénin ${ }^{2}$ Laboratoire d'Analyse des eaux de la Société d'Exploitation des Eaux du Niger (SEEN) de Zinder, Zinder, Niger ${ }^{3}$ Département de Chimie, Faculté des Sciences et Techniques, Université Abdou Moumouni, Niamey, Niger ${ }^{4}$ Laboratoire d'Étude et de Recherche en Chimie Appliquée (LERCA), École Polytechnique d'Abomey-Calavi (EPAC), Université d'Abomey-Calavi, Cotonou, Bénin

Email: *sirete2000@yahoo.fr
\end{abstract}

How to cite this paper: Issa, S., Mama, D. Zanguina, A., Natatou, I., Boukari, M. and Sohounhloué, D. (2017) Study of Microbiological Quality along the Water Chain in Belbedji in the Republic of Niger. Journal of Environmental Protection, 8, 787-798. https://doi.org/10.4236/jep.2017.87049

Received: May 11, 2017

Accepted: June 26, 2017

Published: June 29, 2017

Copyright (c) 2017 by authors and Scientific Research Publishing Inc. This work is licensed under the Creative Commons Attribution International License (CC BY 4.0).

http://creativecommons.org/licenses/by/4.0/

\begin{abstract}
This work deals with the microbiological study along the water chain in Belbedji, a local government in the northwest of the Zinder region in the Republic of Niger. For this study, two (2) standpipes, thirty (30) families and ninety (90) samples were selected in order to follow the variation of water microbiological quality. For that the parameters studied are the total coliforms, the fecal coliforms and the E. coli. From these parameters we calculated the indication or the index of the microbiological quality (MQI) by the method of Bovesse and Depelchin, 1980. The variations of the fecal contamination at the level of the families in the different phases are represented on maps. At the water marker, $100 \%$ of families have good microbiological quality. After the transport of water, on $3.33 \%$ of the families the quality of the water deteriorated. After water storage, $16.66 \%$ of families had deteriorated water quality, with the passage of fecal contamination from zero to low on $13.33 \%$ of families, and fecal contamination from zero to moderate $3.33 \%$ of families.
\end{abstract}

\section{Keywords}

Water, Pollution, Microbiological Quality Index, Belbedji, Niger

\section{Introduction}

Water is a rare resource common to all humanity [1]. Access to safe drinking water is at the core of most public health problems in developing countries [2]. The World Health Organization estimates that nearly 500 million people are confronted of infectious diseases of hydric origin, and that 20 million of these 
are dying, so that the microbiological quality of water remains the number one public health concern worldwide [3] [4] [5]. In addition, bacterial contamination in water is a natural phenomenon, in which humans act as primary contaminants, but also as secondary receptors for bacteria present in the environment [3]. However, the preservation of water quality is necessary for sustainable development and health maintenance [6]. Unfortunately, in Africa south of the Sahara, more than a third of the population suffers from consequent diseases of the poor quality of this raw material essential for human life [7]. Thus, microbiological infections most common of these water-related diseases are caused by three main types of microorganisms found in water: bacteria, viruses and protozoa [8] [9]. In view of the degradation of water quality, the first criterion for drinking water quality is the absence of bacterial contamination of fecal origin [10] [11] [12]. Belbedji the targeted area of our study, located in Niger, is almost completely served by drinking water from groundwater [13]. Among the bacteria present in the waters, the groups of total germs, total coliforms and E. coli are analyzed. Their dynamics were followed on the water standpipe and on the entire water chain of the thirty (30) sectioned families.

The purpose of this study is to determine the bacteriological quality of water by the study of the Microbiological Quality Index (MQI) in order to inform on the one hand the riparian populations that use it and on the other hand the $\mathrm{Di}$ rection Belbedji Hydraulic and Sanitation Department (DDHA/B) and the Zinder Regional Hydraulic and Sanitation Directorate (DRHA/Z) on the bacteriological status of these waters, the sources of Contamination and the measures to be taken.

\section{Materials and Methods}

The study is centered on thirty (30) families selected for samplingand on ninety (90) samples, this sampling was done as described by the SEEN [14]. All these families obtain water from two standpipes in the town of Belbedji (Figure 3).

Within the framework of our study three bacteriological measurements were carried out [14], that is respectively during the taking from thestandpipes, after the transport and after the storage of this water in the families in 2015.

In this study, the analyzed parameters are the total germs, total coliforms, fecal $E$. coli by the method of colimetry on membrane filter.

The method of data processing is based on the indication of fecal contamination (Bovesse and Depelchin, 1980), called the microbiological quality index (MQI). The MQI is calculated from water concentrations in total, fecal and $E$. coli coliforms.

Five concentration classes are defined for each of these parameters (Table 1). The MQI is the average of the class numbers of each parameter. The classification of the polluted parameters is carried out according to five quality classes (Table 2) corresponding to the standard colors (Figure 1). 
Table 1. Quality classes corresponding to the different parameters.

\begin{tabular}{cccc}
\hline Classes & Total Bacteria/ml & Fecal Coliforms $/ \mathrm{ml}$ & Fecal Streptococci $/ \mathrm{ml}$ \\
\hline 5 & $<2000$ & $<100$ & $<5$ \\
4 & $2000-9000$ & $100-500$ & $5-10$ \\
3 & $9000-45,000$ & $500-2500$ & $10-50$ \\
2 & $45,000-360,000$ & $2500-20,000$ & $50-500$ \\
1 & $>360,000$ & $>20,000$ & $>500$ \\
\hline
\end{tabular}

Table 2. Classification of polluted parameters according to five quality classes (MQI). IQM Fecal contamination.

\begin{tabular}{cc}
\hline MQI & Fecal Contamination \\
\hline $4.3-5.0$ & Null \\
$3.5-4.2$ & Low \\
$2.7-3.4$ & Moderate \\
$1.9-2.6$ & Strong \\
$1.0-1.8$ & Verystrong \\
\hline
\end{tabular}

\begin{tabular}{|c|}
\hline Null Pollution \\
\hline Low pollution \\
\hline Moderate pollution \\
\hline Strong Pollution \\
\hline Verystrong pollution \\
\hline
\end{tabular}

Figure 1. Quality classes corresponding to standard colors.

\section{Outcome and Interpretation}

Belbedji our study area is a local government located in the northwest of the Zinder region (Figure 2).

Figures 3-7 show the variations of physicalparameters and of the mineralization on the twostandpipeswhich serve the differentfamiliesselected.

Figure 8 shows the distribution of the different families selected for this study and sampled in the three phases.

We present interpretations of the calculated values of the microbiological water quality index from the results of the bacteriological analyzes of the water sampled at the different stages of the water chain in each family (Table 3 ).

The interpretation of the values of the microbiological quality index (MQI) to the water standpipes sampling after the transport and storage of water in families, which are sourced from standpoint, indicates The level of fecal contamination of water (Figures 9-11).

Of all the families buying on the water standpipe $1,4.3<\mathrm{MQI}<5$, which means that there is no fecal contamination at the standpipe 1 water abstraction. After water transport, $6.66 \%$ of the families saw their MQI vary from $4.3<\mathrm{MQI}$ 
$<5$ to $3.5<\mathrm{MQI}<4.2$ which means that the fecal contamination went from zero to low, Resulting in a deterioration in the microbiological quality of the water between the standpipe 1 sampling and the transport. After water storage, 20\% of families saw their MQI ranging from $4.3<\mathrm{MQI}<5$ to $3.5<\mathrm{MQI}<4$.2, which means that fecal contamination went from null to low showing an increase in the deterioration of the microbiological quality of the water between the first

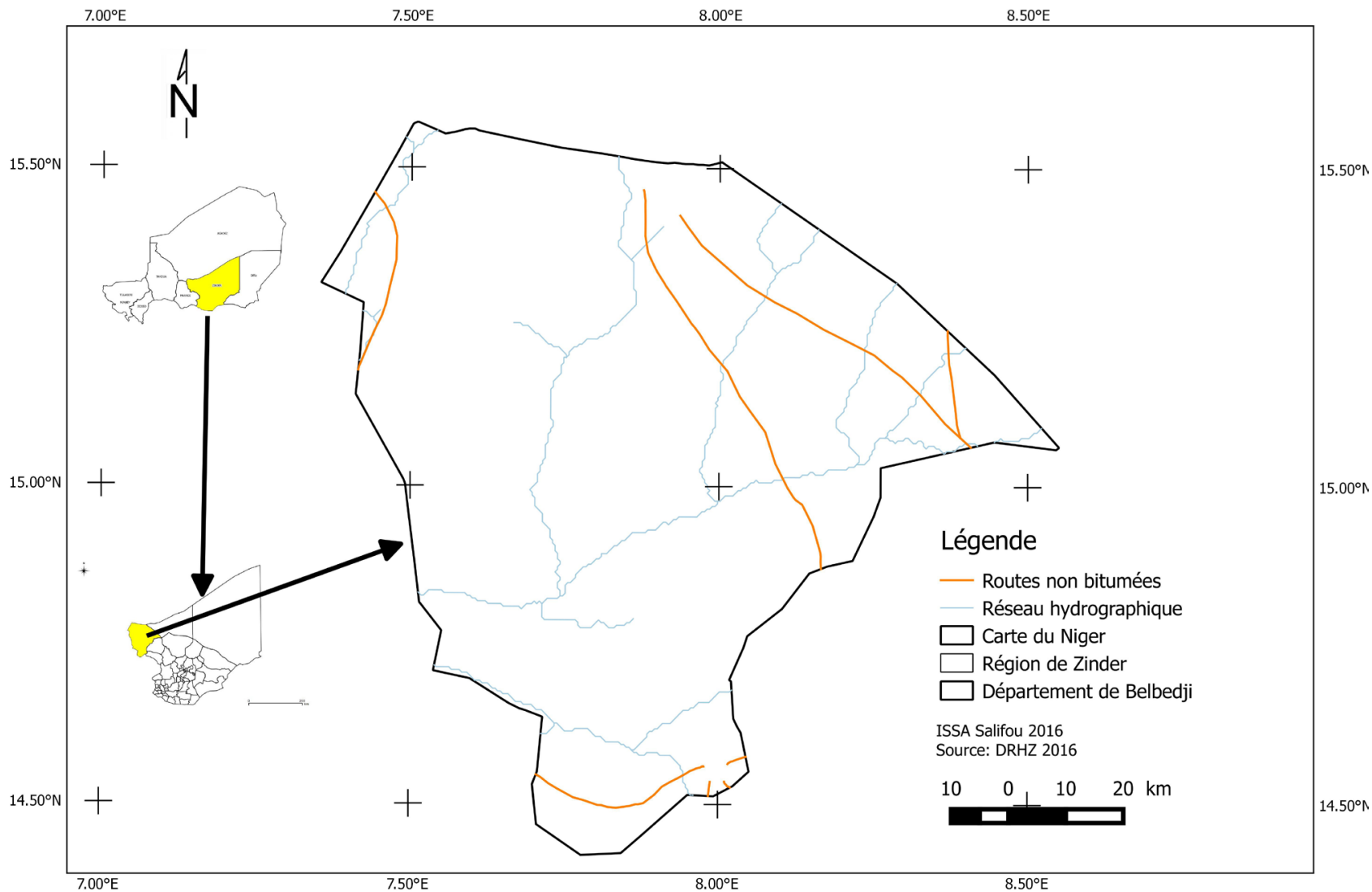

Figure 2. The geographical location of Belbedji local government.

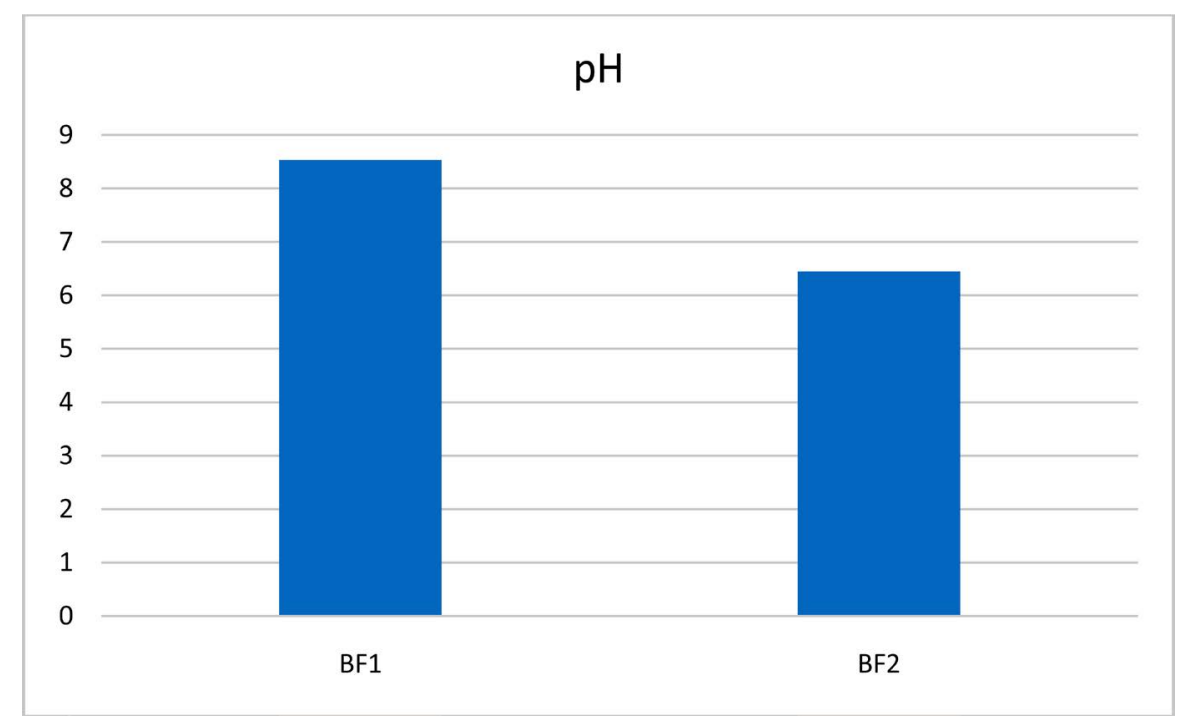

Figure 3. $\mathrm{pH}$ variation on $\mathrm{BF}$. The $\mathrm{pH}$ of these waters varies fromneutral to basic. 


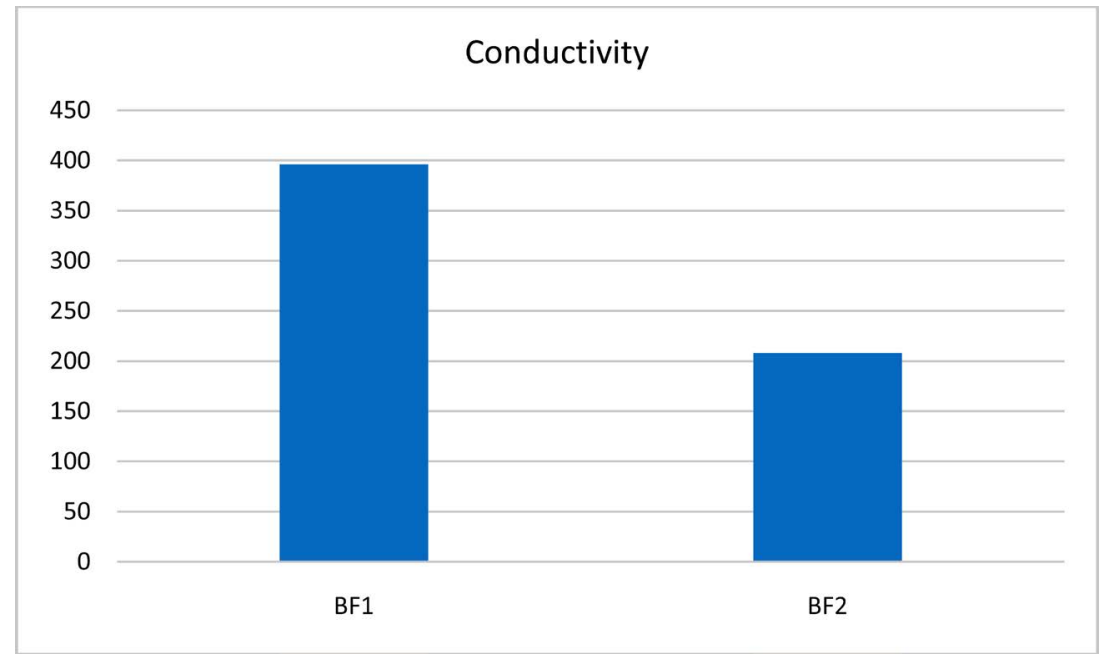

Figure 4. Conductivity variation on BF. The values of the conductivity show us that the mineralization of these waters varies frommoderate to strong [15].

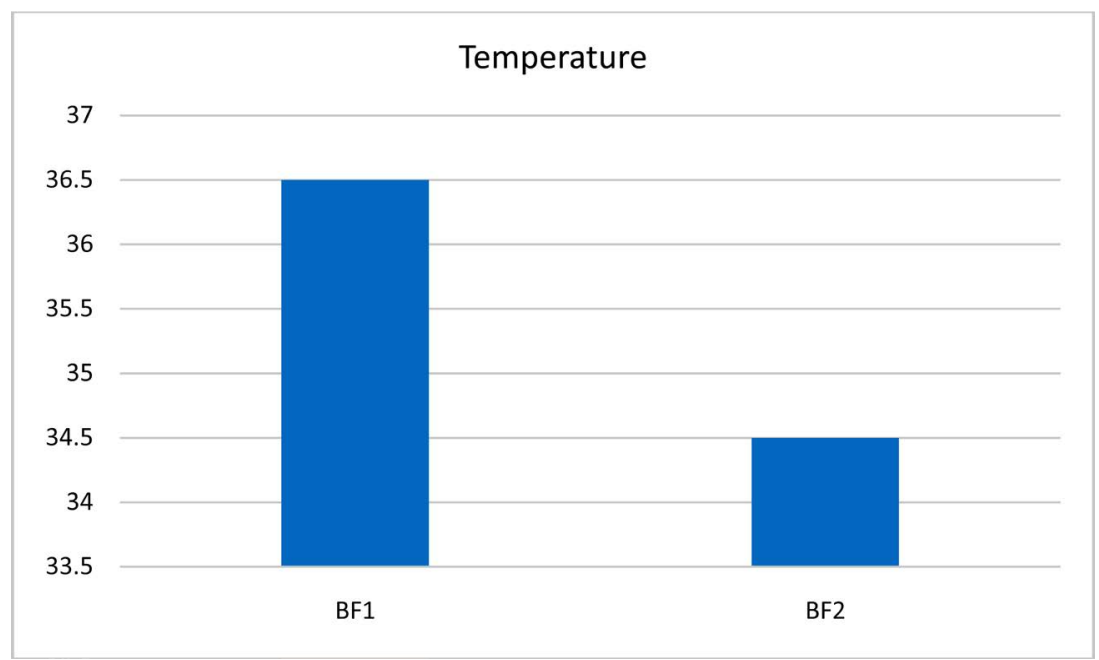

Figure 5. Temperaturevariation on BF.

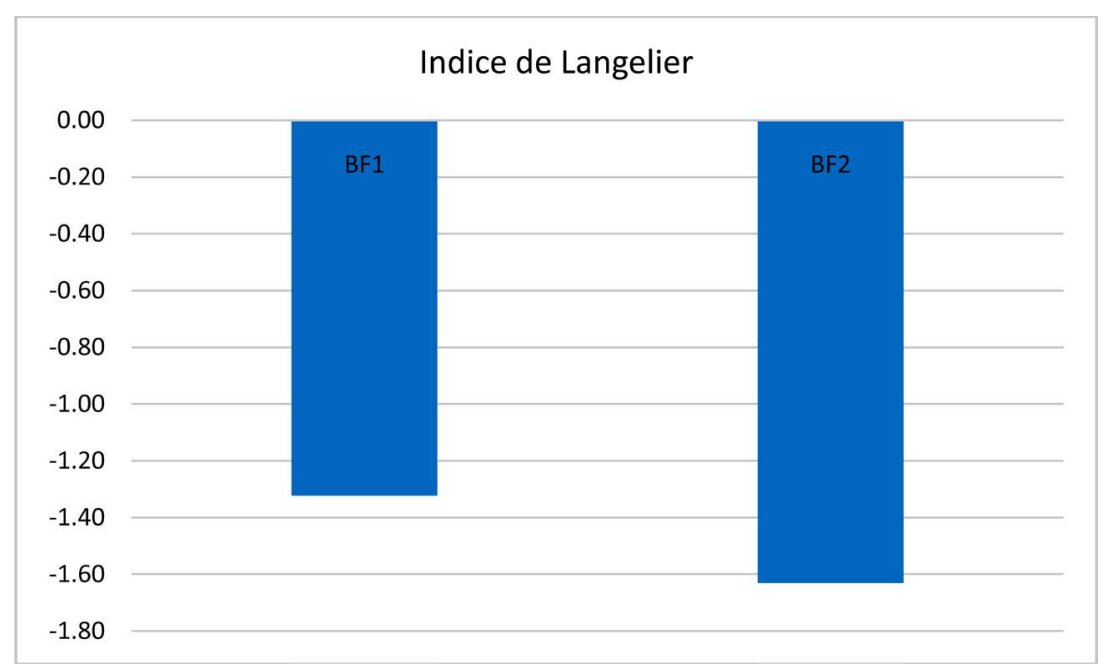

Figure 6. LANGELIER index variation on BF. The analysis of these waters.in relation to the Langelier index shows us thatthese waters are aggressive. 


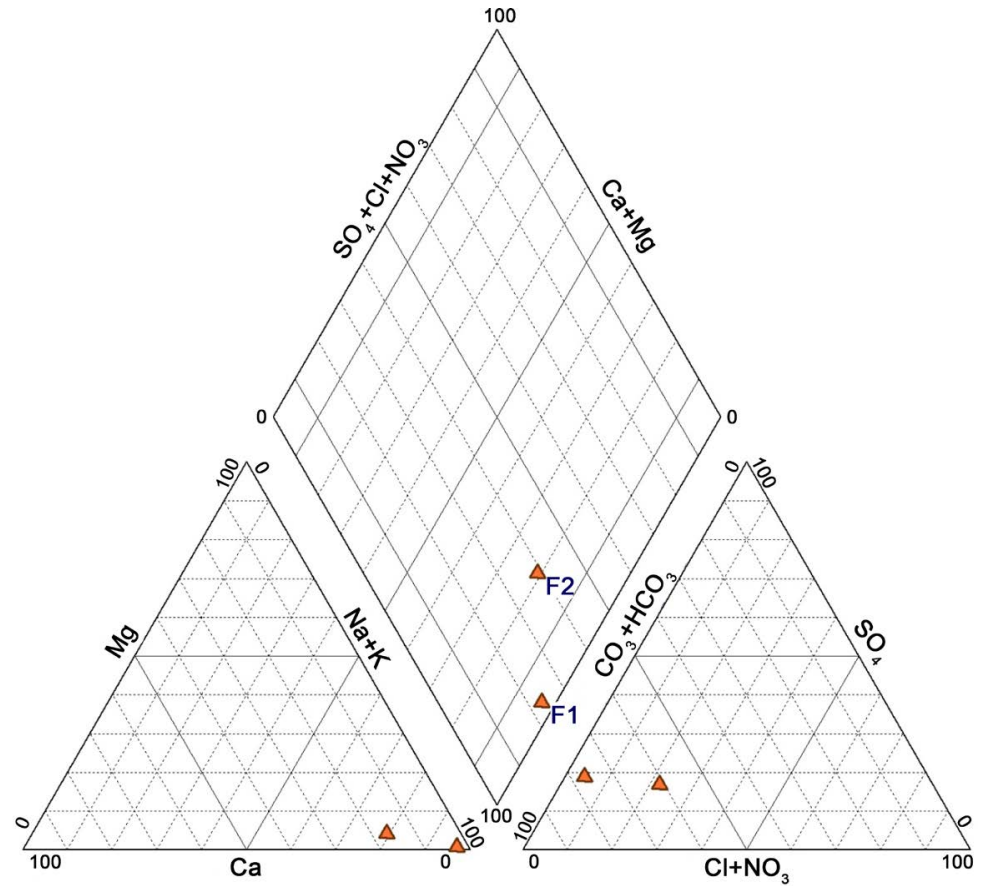

Figure 7. Facies variation on BF. L'analyse du diagramme de piper nous montre que ces eaux sont de faciès bicarbonaté sodique. The analysis of the piper diagram shows thatthese waters have a sodium bicarbonate facies.

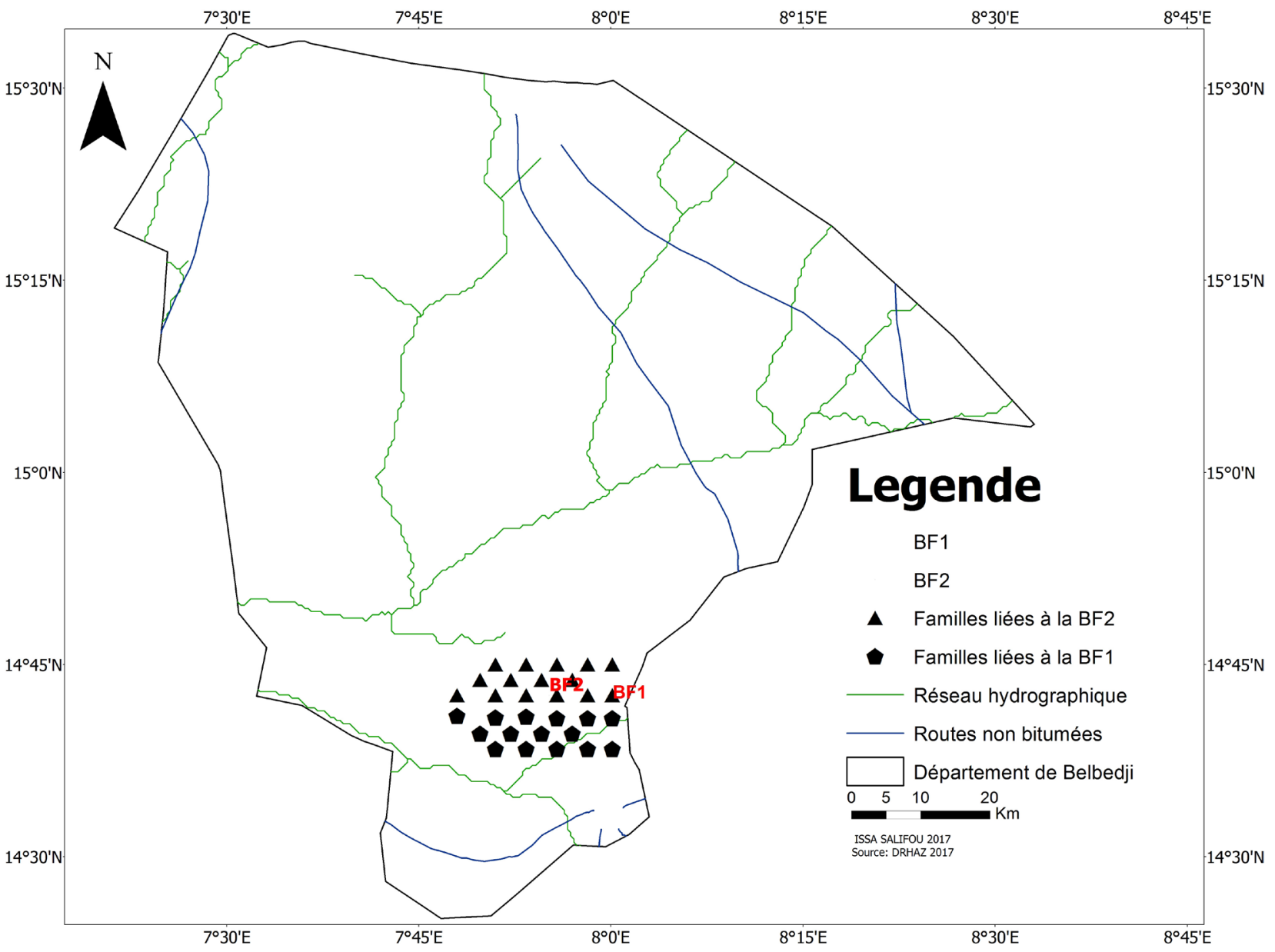

Figure 8. Location map of sample families. 
Table 3. Values of the MQI at the water standpipe, after transport and storage of water.

\begin{tabular}{|c|c|c|c|c|}
\hline \multirow{2}{*}{ Work } & \multirow{2}{*}{ Families } & \multicolumn{3}{|c|}{ Microbiological Quality Index (MQI) } \\
\hline & & At water sampling at standpipe & After transport of water & After storage of water \\
\hline \multirow[t]{15}{*}{ Water standpipe1 } & $\mathrm{F} 1$ & 5 & 5 & 5 \\
\hline & $\mathrm{F} 2$ & 5 & 5 & 4 \\
\hline & F3 & 5 & 5 & 5 \\
\hline & $\mathrm{F} 4$ & 5 & 5 & 5 \\
\hline & F5 & 5 & 5 & 5 \\
\hline & F6 & 5 & 4 & 5 \\
\hline & F7 & 5 & 5 & 5 \\
\hline & F8 & 5 & 5 & 5 \\
\hline & F9 & 5 & 5 & 4 \\
\hline & F10 & 5 & 5 & 4 \\
\hline & F11 & 5 & 5 & 4.5 \\
\hline & F12 & 5 & 5 & 5 \\
\hline & $\mathrm{F} 13$ & 5 & 5 & 5 \\
\hline & F14 & 5 & 5 & 5 \\
\hline & F15 & 5 & 5 & 5 \\
\hline \multirow[t]{15}{*}{ Water Standpipe 2} & F16 & 5 & 5 & 5 \\
\hline & F17 & 5 & 5 & 5 \\
\hline & F18 & 5 & 4.5 & 5 \\
\hline & F19 & 5 & 5 & 5 \\
\hline & F20 & 5 & 5 & 5 \\
\hline & $\mathrm{F} 21$ & 5 & 5 & 5 \\
\hline & $\mathrm{F} 22$ & 5 & 5 & 5 \\
\hline & F23 & 5 & 5 & 4 \\
\hline & $\mathrm{F} 24$ & 5 & 5 & 5 \\
\hline & F25 & 5 & 5 & 5 \\
\hline & F26 & 5 & 5 & 5 \\
\hline & $\mathrm{F} 27$ & 5 & 5 & 5 \\
\hline & $\mathrm{F} 28$ & 5 & 5 & 5 \\
\hline & F29 & 5 & 5 & 5 \\
\hline & $\mathrm{F} 30$ & 5 & 5 & 3 \\
\hline
\end{tabular}




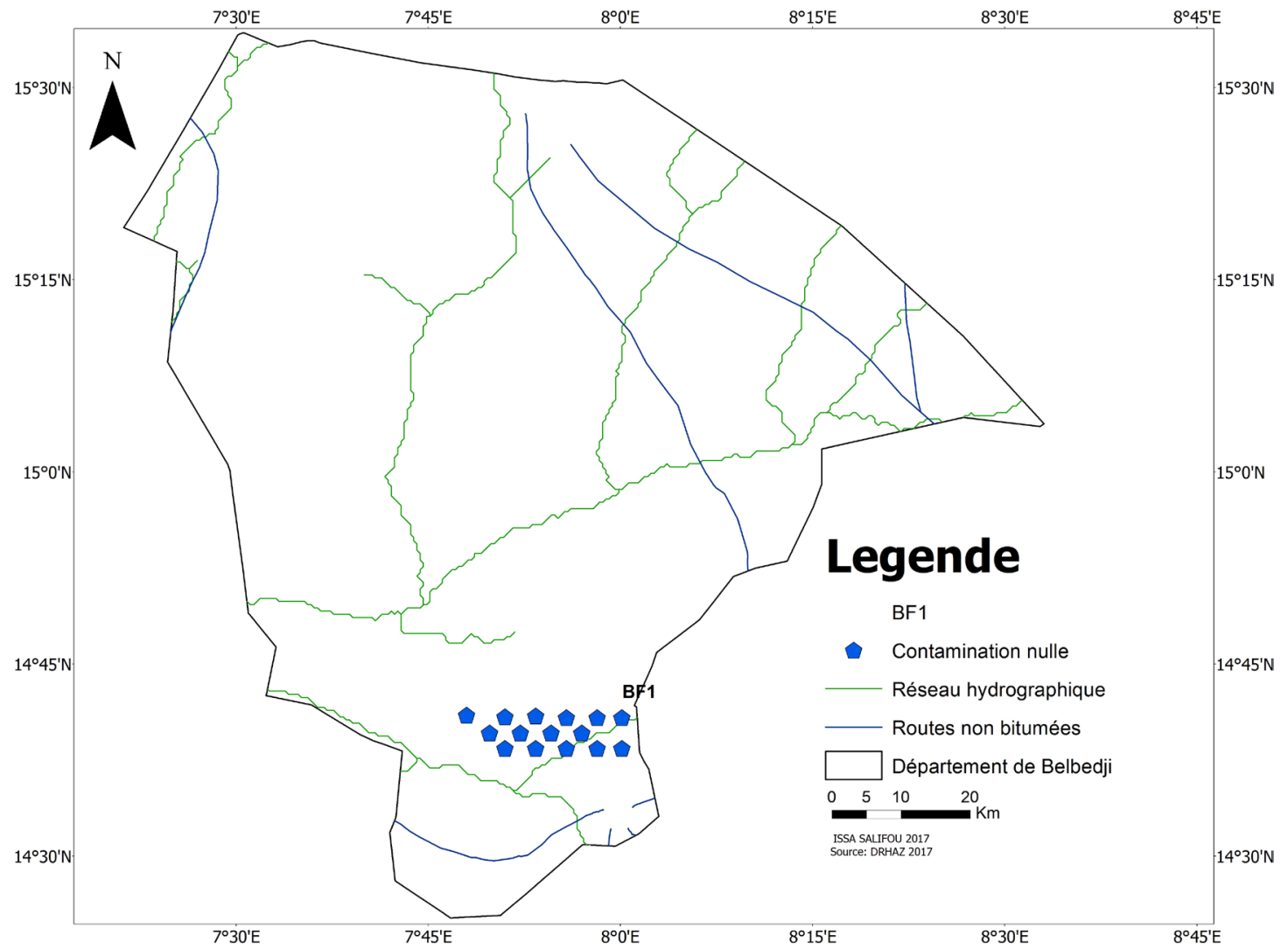

Figure 9. Map of variation in fecal contamination at water standpipe 1 abstraction.

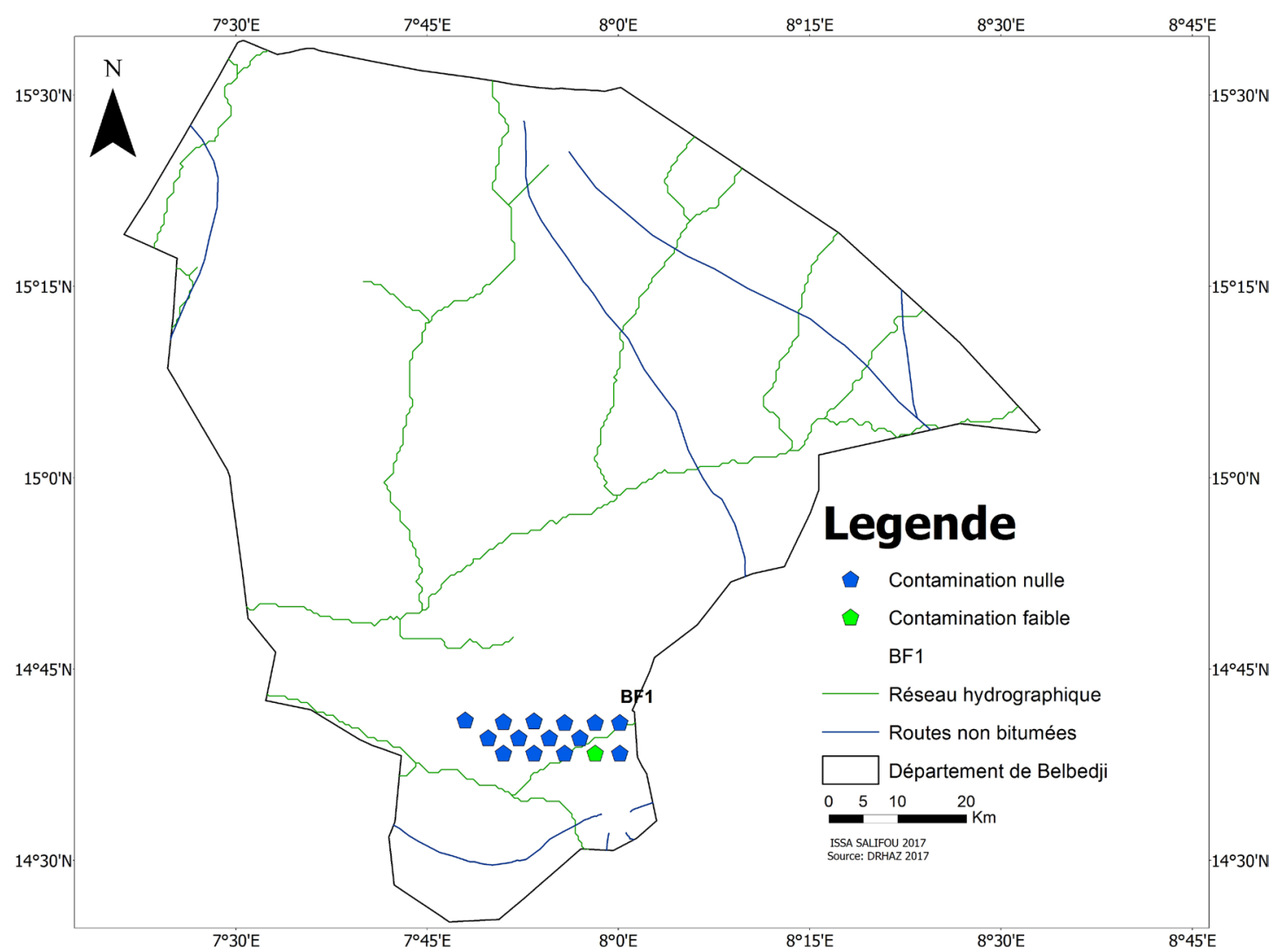

Figure 10. Map of the variation in fecal contamination after water transport by families. 


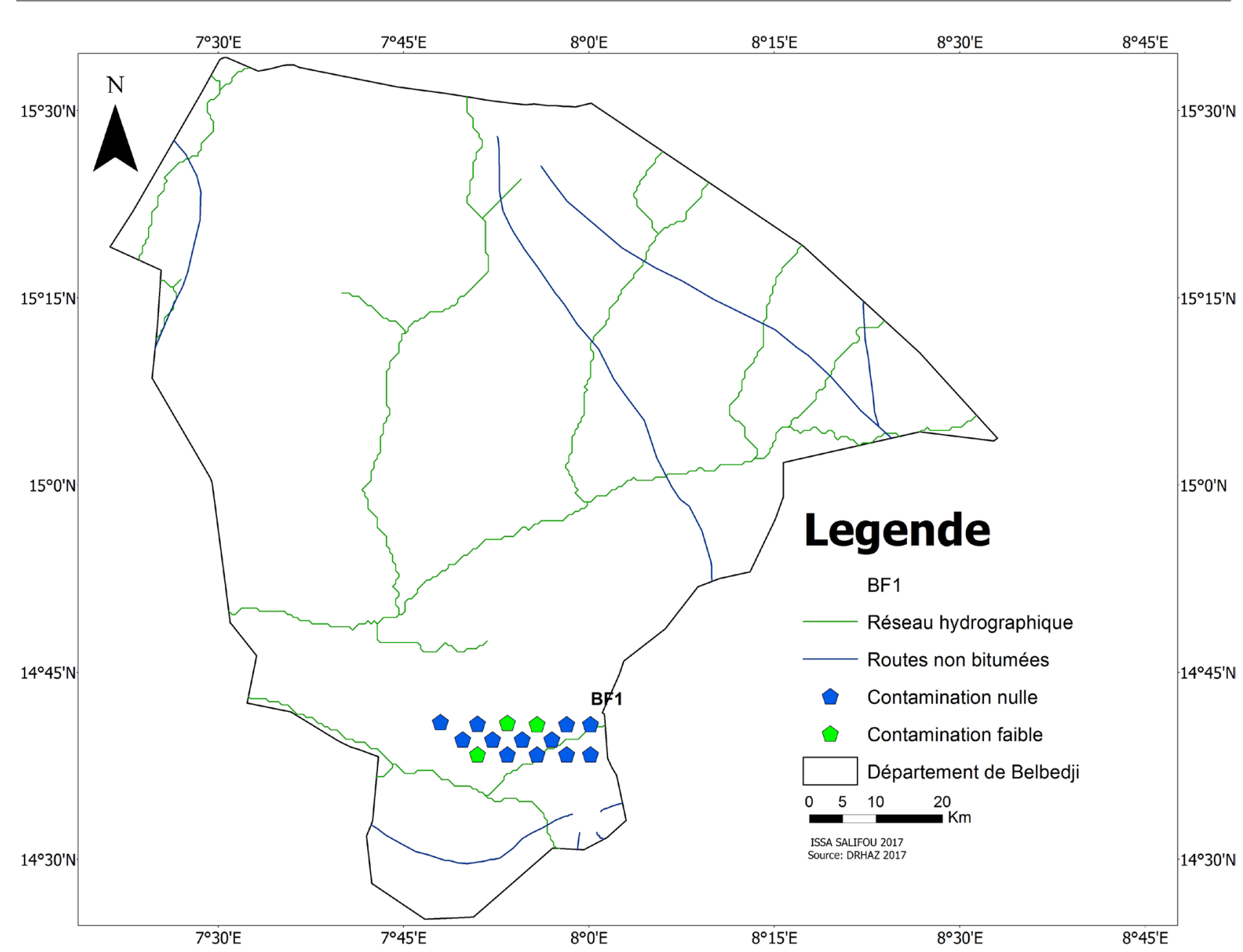

Figure 11. Map of the variation in fecal contamination after water storage in families.

sample and the storage. Thus, the quality of the water deteriorated during its transport and in a more pronounced way during its storage in the families.

The interpretation of the values of the microbiological quality index (MQI) to the water standpipe sample, after the transport and storage of water in the families, which are sourced from water standpipe 2 , indicates The level of fecal contamination of water (Figure 12 and Figure 13).

On the whole families getting water supply from the standpipe 2, 4, $3<\mathrm{MQI}<$ 5 , which means that fecal contamination is null to the taking of water from the standpipe 2 and after its transport. Hence a conservation of the microbiological quality of the water between its sampling at standpipe 2 and its transport. After storage of water, $13.33 \%$ of the families saw their MQI vary, of which $6.66 \%$ was $4.3<\mathrm{MQI}<5$ to $3.5<\mathrm{MQI}<4.2$, which means that fecal contamination has gone from null to low and the remaining $6.66 \%$ from $4.3<\mathrm{MQI}<5$ to $2.7<$ MQI $<3.4$, which means that this fecal contamination has gone from zero to moderate, A significant deterioration in the microbiological quality of water between standpipe 2 sampling and storage.

We see fecal contamination of water during transport and storage in families.

This deterioration in the quality of the water may be linked to pollution from 


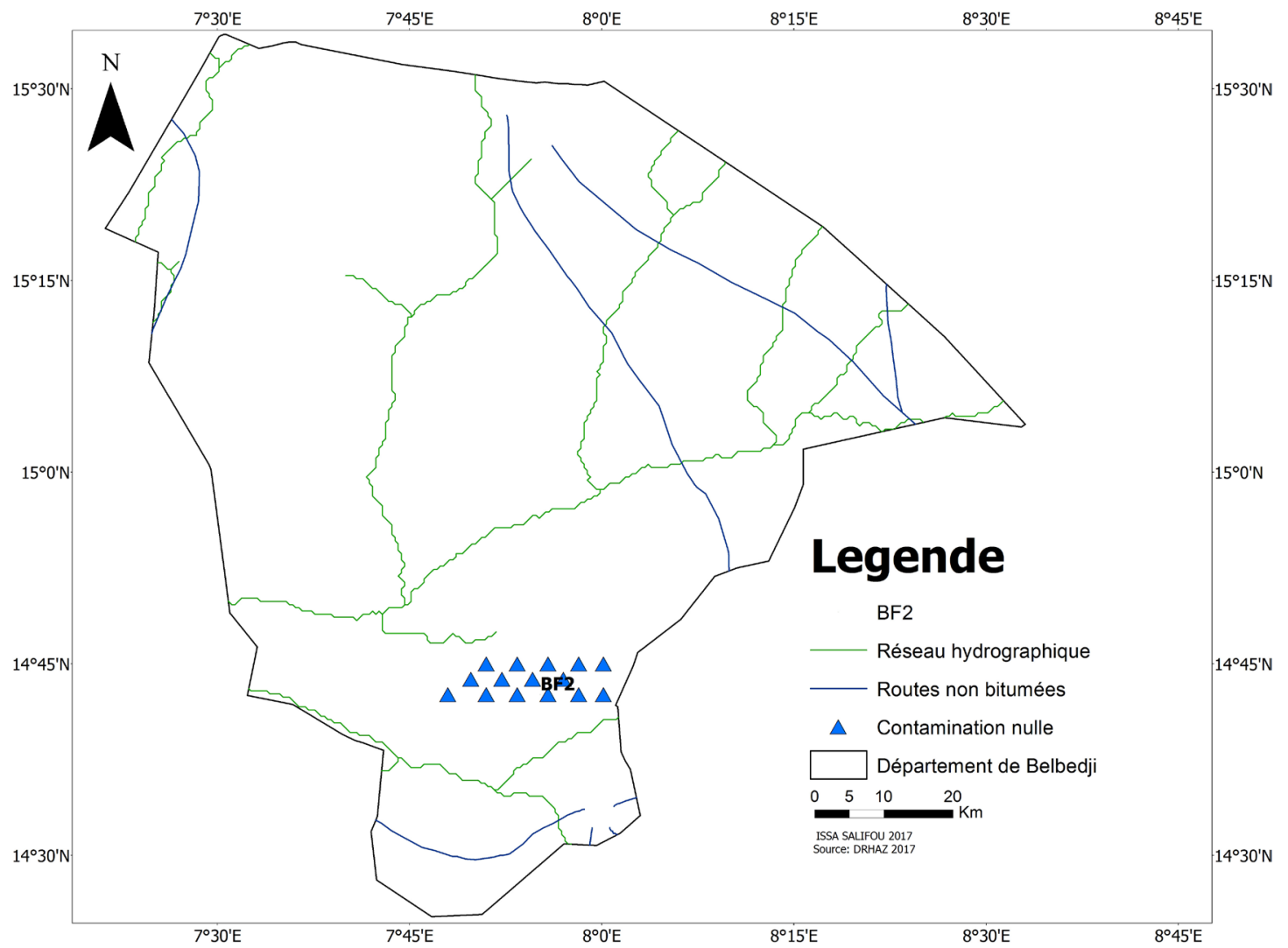

Figure 12. Map of fecal contamination variation at sample taking at water standpipe 2 and after transport of water by the families.

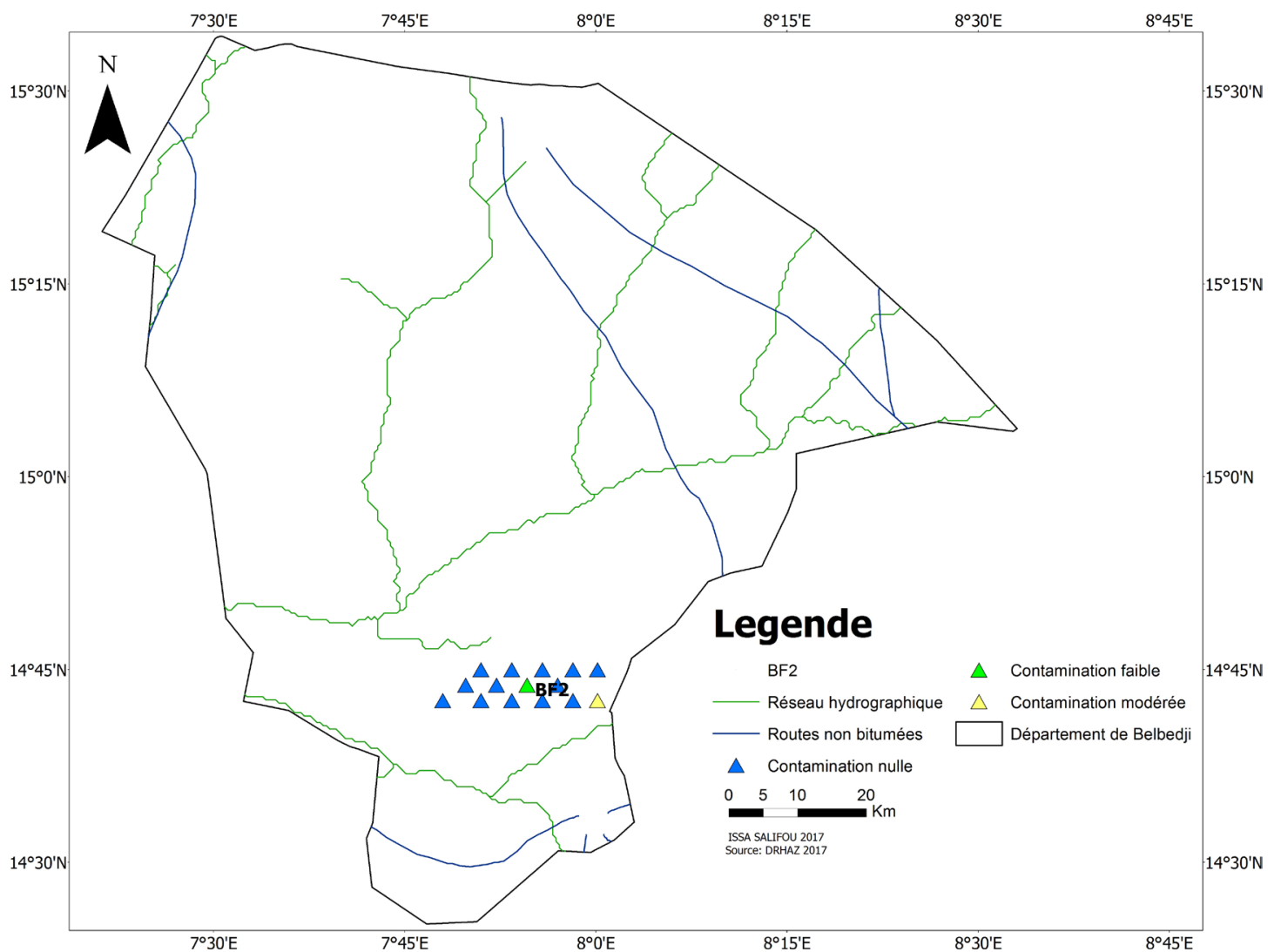

Figure 13. Map of fecal contamination variation after storage of water in the families. 
the container used for transport, which on the one hand is not cleaned before use and, on the other hand, does not sometimes have an airtight lid. Another source of pollution is the person who carries, due to lack of hygiene.

This fecal pollution is due to the lack of use of soap by families after defecation and during water manipulation.

\section{Conclusion and Recommendations}

At the end of this study, we find that the water taken by $100 \%$ of families at the standpoints is free from fecal contamination. However, on $3.33 \%$ of families we see deterioration in the quality of the water after its transport, with the passage of fecal contamination from zero to low. Also on $16.66 \%$ of families we are witnessed deterioration in the quality of water after storage, with respectively the passage of fecal contamination from zero to low on $13.33 \%$ of families, and the passage of fecal contamination from zero to moderate on $3.33 \%$ of families.

Thus a water of good microbiological quality during its sampling can see its quality deteriorate during its transport and especially during its storage in the families.

This bacteriological pollution of water isanthropic in nature and islinked to the lack of hygiene of the populations thatmanipulateit.

These results should concern the structures concerned with the production of drinking water in the area studied, in particular the DDHA/B, the DRHA/Zet and the Ministry of Hydraulics and Sanitation. These structures must set up a Program of information, education and communication directed towards the populations to make them acquire behaviors favorable to the preservation, the potability of water from its source of supply until its consumption, to preserve peoples from diseases related to microbiological pollution of water that can lead to death.

\section{References}

[1] Salifou, I., Abdoukarim, A., Zanguina, A., Ibrahim, N., Mousa, B., Dominique, S. and Daouda, M, (2015) Hydrogeochemical Characterization of Continental Intercalary, Terminal, the Base and the Korama Aquifers Groundwater Found in fivenlocal Governments in the Zinder region in the Republic of Niger. Research Journal of Chemical \& Environmental Sciences, 3, 9-16.

[2] Hounsou, M.B., Agbossou, E.K., Ahamide, B. and Akponikpe, I. (2010) Qualité bactériologique de l'eau du bassin de l'Ouémé: Cas des coliformes totaux et fécaux dans les retenues d'eau de l'Okpara, de Djougou et de Savalou au Bénin. International Journal of Biological and Chemical Sciences, 4, 377-390. https://doi.org/10.4314/ijbcs.v4i2.58128

[3] Gantzer, C.A.P., Audic, J.M. and Schwartzbrod, L. (1998) Detection of Infectious Enteroviruses, Enterovirus Genomes, Somatic Coliphages, and Bacteroides fragilis Phages in Treated Wastewater. Applied and Environmental Microbiology, 64, 43074312.

[4] ONU (2007) L'eau une responsabilité partagée, 2ème Rapport mondial des Nations Unies sur la mise en valeur des ressources en eau.

http://www.unesco.org/water/wwap/index_fr.shtml 
[5] Constantin, M., Leroux, R., Amable, M.-C., Mesnardrobbe, A. and Rimbault, C. (2007) L'eau en capitale. Paris Info.

[6] Makoutodé, M., Assani, A.K., Ouendo, E.-M., Agueh, V.D. and Diallo, P. (1999) Qualité et mode de gestion de l'eau de puits en milieu rural au Bénin: Cas de la sous-préfecture de Grand-Popo. Médecined Afrique Noire, 46, 7.

[7] Mérino, M. (2008) L'eau: Quels enjeux pour l'Afrique subsaharienne? CREPAO, Note $\mathrm{n}^{\circ} 20$ de la Fondation pour la Recherche Stratégique (FRS), Université de Pau et des Pays de l'Adour.

[8] Zogo, D. (1980) Caractéristiques physicochimiques, bactériologiques et traitements des eaux de consommation en République Populaire du Bénin. Mémoire de fin d'étude, Collège Polytechnique Université d'Abomey-Calavi, Bénin.

[9] David, R.B. (2006) L'eau que nous buvons. Les normes et recommandations en matière de qualité de l'eau potable-une comparaison internationale. Rapport de la série un environnement en santé des canadiens en santé. $45 \mathrm{p}$. http://www.davidsuzuki.org/publications/downloads/2006/dsf-hehc-water-fr.pdf

[10] WHO (1993) Guidelines for Drinking-Water Quality. Recommendations. Chemical aspects. World Health Organisation of the United Nations, 2nd Edition, Vol. 1. Geneva. http://www.who.int/water_sanitation_health/dwq/2edvol2p2a.pdf

[11] MSP (2001) Décret $n^{\circ}$ 2001-094 du 20 février 2001 fixant normes de qualité de l'eau potable en République du Bénin.

[12] Miquel, G. (2003) Eau: Qualité et assainissement, Rapport sur la qualité de l'eau et de l'assainissement en France $n^{\circ} 705$. http://www.assemblee-nationale.fr/12/dossiers/030705.asp

[13] Salifou, I., Abdoukarim, A., Ibrahim, N., Mousa, B., Dominique, S. and Daouda, M. (2015) Caractéristique hydrogéochimique des eaux souterraines des aquifères de l'Izegouandé et du Tarat au voisinage de la Somaïr à Arlit au Niger. J. Soc. OuestAfr. Chim, 39, 57-63.

[14] SEEN (2016) Protocoles de prélèvements et analyses de l'eau. Document interne, laboratoire d'analyses de l'eau de Zinder, Niger.

[15] Rodier, J. (1978) Analyse de l'eau. Edition Dunod, Paris.

\section{Submit or recommend next manuscript to SCIRP and we will provide best service for you:}

Accepting pre-submission inquiries through Email, Facebook, LinkedIn, Twitter, etc. A wide selection of journals (inclusive of 9 subjects, more than 200 journals)

Providing 24-hour high-quality service

User-friendly online submission system

Fair and swift peer-review system

Efficient typesetting and proofreading procedure

Display of the result of downloads and visits, as well as the number of cited articles

Maximum dissemination of your research work

Submit your manuscript at: http://papersubmission.scirp.org/

Or contact jep@scirp.org 